\title{
Endoscopic full-thickness resection for diagnosis of Hirschsprung's disease
}
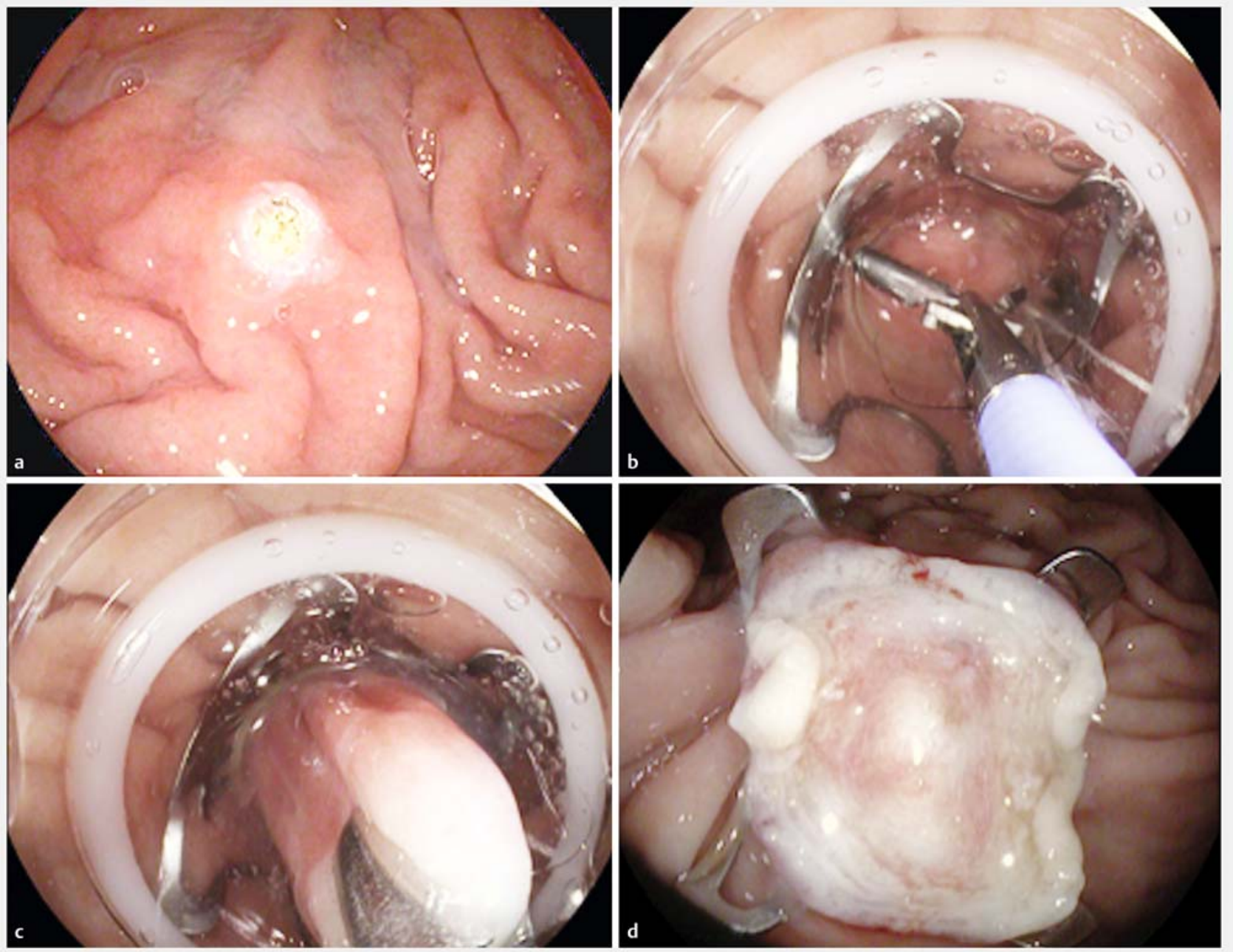

- Fig. 1 Endoscopic images showing: a the lesion being marked; $\mathbf{b}$ the tissue being pulled inside the transparent distal cap; $\mathbf{c}$ the pulled-in tissue being snared; $\mathbf{d}$ the resection site with over-the-scope clip (OTSC) in situ.

Endoscopic full-thickness resection (EFTR) is beneficial for treating a variety of conditions of the lower gastrointestinal tract such as early cancers, polyps, and fistulas [1,2]. Whereas the role of EFTR in the therapy for these conditions has been proven to be effective and safe, there is a paucity of data about its potential utility as a diagnostic intervention in patients with gastrointestinal tract dysmotility disorders [3]

In this report, we present a 19-year-old woman with chronic constipation since childhood, which remained severe, despite the use of multiples laxatives, along with dietary and lifestyle changes. Apart from the severe, recalcitrant constipation, the patient had no significant past medical history. The family history, however, was positive for achalasia in her mother.

The patient underwent several diagnostic interventions. A colonoscopy was unrevealing, except for massive dilatation of the sigmoid and descending colon and stool retention despite aggressive bowel prep and intraprocedural bowel cleansing. Histology obtained using the biopsy-on-biopsy technique was unrevealing. Both anorectal manometry and barium enema were suggestive of Hirschsprung's disease. To obtain a definitive diagnosis, a full-thickness tissue sample was required. Traditionally, surgery is mandatory to obtain such tissue. However, the advent of the EFTR device (Ovesco, Tübingen, Germany) allows for the retrieval of the entire wall of the gastrointestinal tract. The patient decided to 


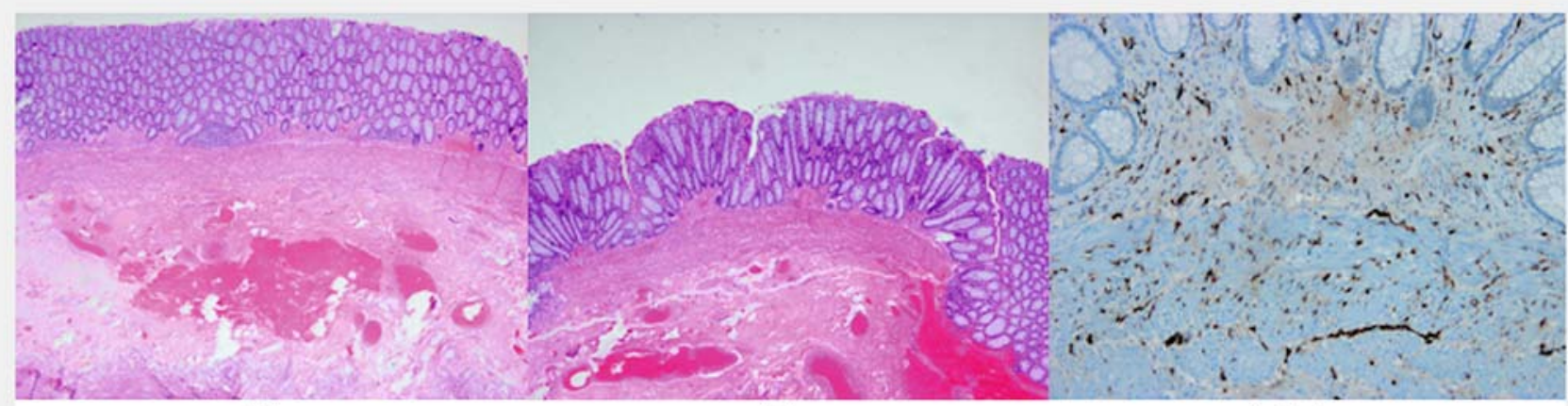

HE

HE

calretinin

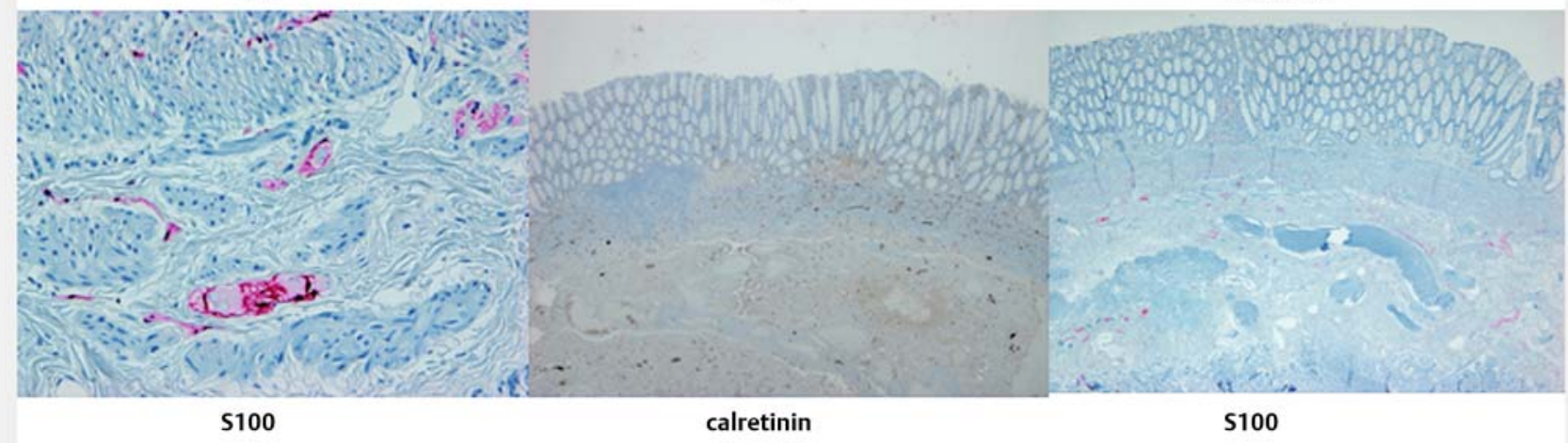

Fig. 2 Histological appearances of the resected specimen stained with hematoxylin and eosin (H\&E) and immunostained with calretinin and S100.

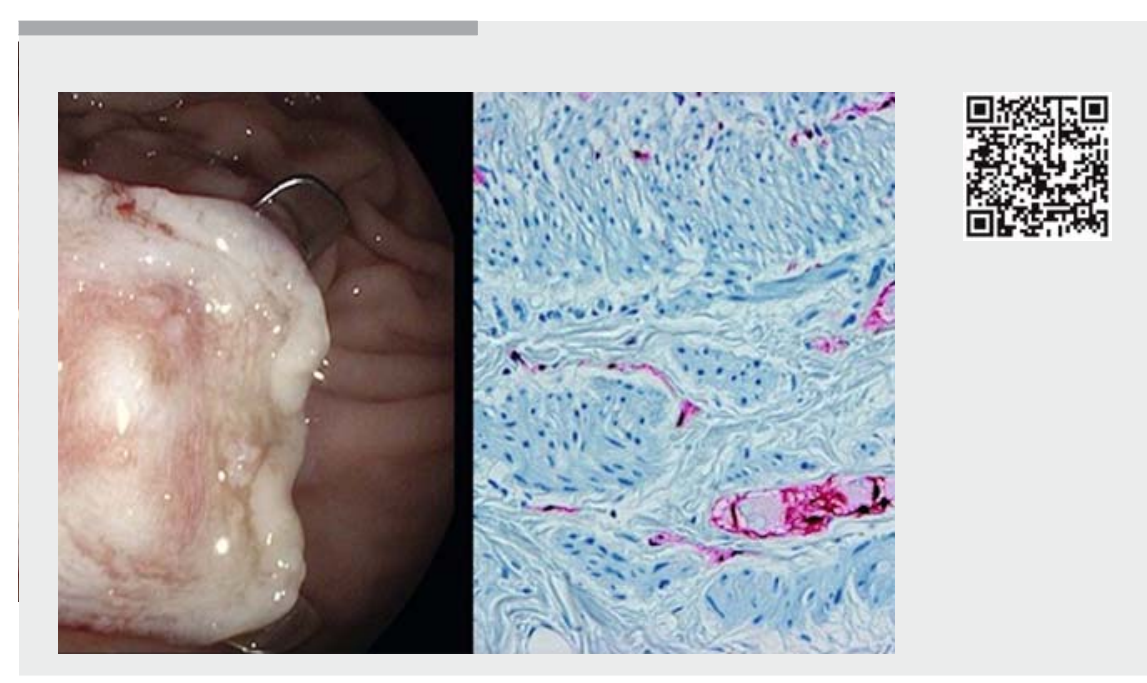

Video 1 Endoscopic full-thickness resection using the Ovesco device including a stepby-step description of the technique, which involves marking of the lesion, grasping and retrieval of the target tissue within the cap then fixation, release of the over-the-scope clip (OTSC) with a hand-wheel, closure of the snare and electrical cutting of the target tissue, and finally inspection of the resection site. accept the use of this method and consented to undergo FTR using endoscopic means (-Fig. 1; - Video 1). The sample obtained was 15-mm wide and included down to the deep submucosal and muscular layers. After performing special immunohistochemical stains (S-100, synaptophysin, calretinin, and neurofilament specific), a diagnosis of hypoganglional disease was reached ( $>$ Fig. 2 )

As we can see in this case, diagnosis by EFTR appears to be a safe, fast, and feasible option to obtain enough tissue from the deeper layers of the rectum to diagnose Hirschsprung's disease and other deep-seated disease processes, instead of the typical invasive surgical procedures. Therefore, the advent of the EFTR device has increased our ability to help patients obtain an earlier diagnosis of their chronic, underlying illness. This case adds to the literature on the diagnostic utility of EFTR.

Endoscopy_UCTN_Code_CCL_1AD_2A J 
None

The authors

Alvaro Martínez-Alcalá1, Felipe Martínez-

Alcalá García ${ }^{1}$, Klaus Mönkemüller², Helmut

Neumann ${ }^{3}$, Felipe Martínez-Alcalá ${ }^{1}$

1 Centro de Innovaciones Digestivas MartínezAlcalá (CIDMA), Seville, Spain

2 Frankenwald Klinik, Kronach, Germany

3 University Medical Center Mainz, Mainz, Germany

\section{Corresponding author}

\section{Alvaro Martínez-Alcalá, MD}

Centro de Innovaciones Digestivas MartínezAlcalá, Endoscopy Unit, Calle San vicente 36, Seville 41002, Spain

Fax: +34-94-5382911

alvaromalcala@gmail.com

\section{References}

[1] Chiang AL, Storm AC, Aihara $\mathrm{H}$ et al. Endoscopic full-thickness resection of fistula tract with suture closure. Endoscopy 2018; 50: E15-E16

[2] Kadkhodayan K, Rafiq E, Hawes RH. Endoscopic evaluation and management of gastric stromal tumors. Curr Treat Options Gastroenterol 2017; 15: $691-700$

[3] Valli PV, Pohl D, Fried M et al. Diagnostic use of endoscopic full-thickness wall resection (eFTR) - a novel minimally invasive technique for colonic tissue sampling in patients with severe gastrointestinal motility disorders. Neurogastroenterol Motil 2000. doi:10.1111/nmo.13153

\section{Bibliography}

DOI https://doi.org/10.1055/a-0642-9017

Published online: 3.7.2018

Endoscopy 2018; 50: E281-E283

(c) Georg Thieme Verlag KG

Stuttgart · New York

ISSN 0013-726X
ENDOSCOPY E-VIDEOS

https://eref.thieme.de/e-videos

口回 Endoscopy E-Videos is a free access online section, reporting 囬: on interesting cases and new techniques in gastroenterological endoscopy. All papers include a high quality video and all contributions are freely accessible online.

This section has its own submission website at https://mc.manuscriptcentral.com/e-videos 